\title{
P 362
}

\section{就労女性と家庭女性の破水率の比較}

\author{
○外間 美智子 ${ }^{1}$ 荃山 充 ${ }^{21}$ 圓藤 吟史 ${ }^{3)}$ \\ 1)石塚助産院 2)かげやま医院 3)大阪市立大学大学院医学研究科都市医学
}

\section{【はじめに】}

助産所にて正常経膣分婏した,就労 女性 1) と家庭女性 2) 前期破水 （PROM）率を比較した。

\section{【対象と方法】}

対象はI 助産院で昭和 62 年 9 月か ら平成 12 年 12 月迄の正常経腔分婏 1061 例（29.0 歳士4.1）であり内訳 は, 就労女性 269 例（28.3 歳士3.8） と家庭女性 792 例 (29.2 歳士4.2) で あった。（I）就労女性と家庭女性 (II) 就労女性での初産婦と経産婦 (III) 家 庭女性での初産婦と経産婦 (IV) 初産 婦と経産婦別での就労女性と家庭女 性の破水率を $\chi^{2}$ 検定した。

\section{【結果】}

（1）就労女性は家庭女性よりも有意 に高い。

（表 1) 就労女性と家庭女性の破水率 $\mathrm{P}<0.001$

\begin{tabular}{|c|c|c|c|}
\hline & 破水(率) & 非破水 & 合計 \\
\hline 就労女性 & $38(14.1 \%)$ & 231 & 269 \\
\hline 家庭女性 & $57(7.2 \%)$ & 735 & 792 \\
\hline 計 & $95(9.0 \%)$ & 966 & 1.061 \\
\hline
\end{tabular}

（II）就労女性では経産婦より初産婦 が有意に高い。

（表 2) 就労女性での初産婦と経産婦の破水率 $\mathrm{P}<\mathbf{0 . 0 1}$

\begin{tabular}{|c|l|c|c|}
\hline 就労女性 & 破水(率) & 非破水 & 合計 \\
\hline 初産婦 & $30(19.1 \%)$ & 125 & 155 \\
\hline 経産婦 & $8(7.1 \%)$ & 106 & 114 \\
\hline 計 & $38(14.1 \%)$ & 231 & 269 \\
\hline
\end{tabular}

（III）家庭女性では経産婦より初産婦 が有意に高い。

（表 3) 家庭女性での初産婦之経産婦の破水率 $\mathrm{P}<0.01$

\begin{tabular}{|c|c|c|c|}
\hline 家庭女性 & 破水(率) & 非破水 & 合計 \\
\hline 初産㛿 & $27(13.1 \%)$ & 179 & 206 \\
\hline 経産㛿 & $30(5.1 \%)$ & 556 & 586 \\
\hline 計 & $57(7.2 \%)$ & 735 & 792 \\
\hline
\end{tabular}

（IV）初産婦・経産婦別では就労女性 と家庭女性の有意差はない。

\section{【考察】}

産休直前迄就労する女性は今後も 増加すると思われる。就労妊婦の健康 管理は今後も重要な課題となろう。

産科上意義のある 37 週末満の破水 （P－PROM） は次回報告を予定してい る。

1）就労女性を, 非常勤（週に 1 日以上 の勤務) や常勤 (週に 5 日以上の勤務) で就労している女性とし, 自営業もし くは共同経営者も含むこととした。 2）家庭女性を,妊娠が確定した時に就 労せず，家事・育児に専念している女 性とした。 